\title{
TECHNIQUES IN PCR AND PCR EVALUATION TECHNOLOGY AND ITS APPLICATION TO THE STUDY OF CEREBROSPINAL FLUID IN HIV DISEASE
}

\author{
Peter Schmid, Andrew Conrad, Karl Syndulko, Elyse J. Singer, \\ Ximing Li, Gongming Tao, Daniel Handley, Bridget Fahy- \\ Chandon, and Wallace W. Tourtellotte \\ Neurology and Research Services \\ VA Medical Center West Los Angeles \\ Los Angeles, California 90073 \\ Department of Neurology \\ University of California School of Medicine \\ Los Angeles, California 90024
}

INTRODUC'TION

An early and substantial involvement of the central nervous system (CNS) in human immunodeficiency virus (HIV) disease became obvious quite soon after the onset of the AIDS epidemic. 1 Clinical classifications have since emerged,2 and the pathological correlates have been described. 3 The direct presence of HIV in the brain in spite of the inability of the virus to pass the blood-brain barrier (BBB) was found and explained by mechanisms in which the virus intracellularly traverses the barrier, in particular through its capacity to infect macrophages. 4

The harmful effects of HIV on the CNS are well documented and range from subtle cognitive or motor neuropsychological findings to the full blown HIV-1 associated cognitive/motor complex. While numerous theories have emerged to account for these CNS effects, the precise pathogenetic pathways have not yet been elucidated. The rare availability of direct tissue material for the study of molecular pathogenesis in the early stages of HIV CNS involvement and the need to conduct longitudinal studies make the cerebrospinal fluid (CSF) a logical choice to investigate viral activity and status in terms of the presence of proviral forms, intensity of cellular lysis, and titer of infective virions both in cellular and noncellular compartments of the CSF. In addition, a comparison of these aspects of viral activity between blood and CSF evaluated directly by quantitative assay of the molecular species representing the genetic material of $H I V$ as it progresses through its life cycle, is likely to provide insight into any special role that the CNS might play through its immunoprivileged position in the overall and intricate mechanisms of pathogenesis, persistence, and resilient adaptation of HIV to the body's natural defense systems. Similarly, a realistic account of the quantitative presence of HIV in the CNS will be necessary to assess the potential limits of efficacy or immunotherapy schemes if the drug in question does not penetrate the BBB. In addition, through the relative ease with which the CSF can be obtained, quantitative studies of the proviral and free virion forms might provide critical markers of actual CNS involvement in a 
particular patient and is likely to serve as a prognostic tool for HIV CNS disease, if such a correlation can indeed be shown.

From the foregoing, the importance of a molecular technique for the reliable quantitative assessment of HIV RNA and DNA forms is obvious, as is the need to conduct longitudinal studies on well-classified cohorts of HIV-positive patients whose neurologic status is routinely examined. The relatively small quantities of HIV nucleic acid materials present in blood and CSF require using an extremely sensitive technique. The polymerase chain reaction (PCR), in principle, can detect such small quantities of nucleic acids, and several methods to perform PCR quantitatively have been reported.5,6 However, PCR is not a specific technique, but rather a wide range of methods that share the principle of cyclic enzymatic replication using thermostable polymerases. A critical integrative analysis of the fundamental aspects of biochemistry, thermocycling, and post-amplification analysis was performed as well as a study of the limitations and hidden possibilities that reside in the hardware. The following will cover some of the concepts and inventive results that have emerged as the results of an optimization development of this important methodology over several years. The last section will present some of the result in the investigation of HIV in the CSF and blood using those techniques and how these findings relate to the clinical disturbances in CNS function.

\section{IMPROVING THE RELIABILITY OF QUANTITATIVE PCR}

The exponential amplification of PCR is also the Achilles heel of PCR quantitation. Inconsistencies in any of the factors that determine the amplification efficiency per individual cycle will lead to an exponential amplification of the resulting tube-to-tube variation as well. This severely limits the use of external quantitative standards in the reaction, and prompted the development of $\mathrm{QC}$ PCR that employs an internal standard in the same reaction vessel. In its most elaborate form for the quantitation of HIV RNA, a competitive standard is already used in the reverse transcription reaction, and the standard has the same length and sequence as the unknown, except for a single restriction site that is later cut to distinguish sample RNA from standard. Perfect cutting efficiency is a prerequisite for this method and due to the need for several standard tubes per sample, the method is very labor-intensive and costly.

An alternate way to address the problem is to identify the sources of tubeto-tube inconsistency and find novel ways to reduce them as much as possible. While inconsistencies resulting from the variable background nucleic acid content of the sample are difficult to reduce (but note below that hot start dramatically reduces these inconsistencies), all the other factors can be increased in precision. The first strategy is to reduce the impact of factor variations by reducing the amplification of errors, which can be mostly directly accomplished by reducing the PCR cycle number to a minimum. However, a decrease in PCR cycle number must be accompanied by a corresponding increase in the sensitivity of post-PCR detection. To underscore this point, a system has been offered that uses such ultrahigh specific activity probes that no PCR is used at all.7 In taking a middle ground position, we believe that "low cycle number low wobble" PCR should be combined with the highest sensitivity and specificity detection method for the amplicon produced.

In comparing the various post-PCR detection methods, it is necessary to consider a number of factors inherent in PCR. Nonspecific background synthesis always exists, even if little or no primer dimer is produced. Therefore, global labelling of all synthesized products through labelled precursors or of all products whose synthesis is initiated from a labelled primer will lead to a high background. While stringent annealing conditions can reduce this background, the price for such high compensatory annealing stringency will be a lower per cycle efficiency with resulting magnification of errors through the need for higher cycle numbers. Fundamentally, electrophoresis of PCR products will have the effect of cleaning the amplicon from masking false synthesis products. Still, if one uses a high-sensitivity detection system, weak bands from very low-copy 
number PCR or from low-cycle number PCR could still be masked inside a smear of unwanted background synthesis. Those effects become very apparent once one leaves the classic $10 \mathrm{ng}$ limit sensitivity of ETBr detection, for example, by using an end-detection system such as digoxigenin binding $A B$ linked to alkaline phosphatase, which can detect 0.01 picogram of DNA on a membrane.

One solution to the problem of background synthesis is the use of productspecific high-activity probes that will ignore all but the specific amplicon band. All these measures increase sensitivity beyond the simple limit of the detection system for the PCR product, since they dramatically reduce background and thereby allow reliable quantitative readings of very small amounts of specific DNA. In turn, the number of cycles used to produce such a signal can be reduced.

A related method, oligomer liquid hybridization followed by gel separation, produces bands consisting of partly double-, partly single-stranded DNA. These bands are less sharp than those obtained in Southern blots, and since there is no transfer to a membrane, radioactive probes are needed for detection. After careful consideration, we found that the most sensitive and specific detection method for the amplification product is a combination of Southern blotting with productspecific probe hybridization. This conclusion was supported by direct comparative studies, where the Southern blot method has been shown to be 10,000 times more sensitive than standard gel detection. 8

Despite these inherent qualifications, the Southern blot-probe detection method of PCR evaluation is typically only used on very limited research samples where only a few PCR runs need to be evaluated. Large numbers of specimens simply cannot be conveniently processed using existing Southern blot technology, 9 since these procedures require many time-consuming steps and skilled personnel are needed to perform these techniques. If the procedure is not optimized, it is likely to fail catastrophically.

In response to this situation, one author (P.S.) has contributed long-term efforts to make the benefits of PCR and Southern blots available to process a very high number of specimens. This was possible through the development of several rather complex, robotic instruments that permit completely operator-independent performance of this procedure from gel electrophoresis to the visualization of bands on the membrane. The system whose technical details cannot be presented in the scope of this chapter, currently provides a maximum capacity of 840 PCR reactions per automated run and a total processing time of approximately 24 hours. One picogram of amplified PCR product can be clearly detected. A further important aspect of such an automatic system is the capacity to optimize several conditions; for example, the concentrations of the various reagents in a PCR reaction, electrophoresis, chemical gel treatment, transfer, hybridization and wash stringencies.

In addition, in any manual set-up for the pipetting, mixing, and incubation steps that need to be done in the pre-PCR phase of the procedure, it is almost impossible to avoid uneven treatment of the different samples. Therefore, the important aspect of uniformity in sample preparation and treatment is further enhanced through the use of automatic processing machines, where samples are placed in a circular fashion on a large centrifuge rotor and reagent addition is done by automatic pipetters that are built into these machines and controlled by a computerized program. The rotor arrangement allows for homogeneous mixing by rapid inversions of rotor direction and reliable collection of small amounts of added reagents or condensation after incubations at high temperatures. Incubations at the various temperatures for the reverse transcription reaction are also done in these computer-controlled processors.

Beyond the advantages of high sensitivity end-product detection that help to reduce the number of required amplification cycles, we also attempted to further improve the sample-to-sample precision that is so critical for the use of quantitative PCR by using external standard. After optimization of the biochemical aspect of the amplification reaction through proper primer selection, magnesium concentration, and determination of optimum annealing temperatures, sample-to-sample variation other than the one inherent to the starting material itself, is mainly caused by trivial factors like pipetting inaccuracy, incomplete evenness of master mixes and reaction assemblies, and most importantly, by 
variations in the thermoprofile between individual tubes as well as the precision of the thermoprofiles. The surprisingly short subcycle times required by "air cyclers" that use the low thermal conductance medium air, alerted us to the fact that heat transfer is not only dependent on latent heat of the transfer medium, but also on the local speed of the transfer medium to overcome the "skin effect" that tends to isolate a tube thermally. While encountering substantial technical difficulties, the logical answer to maximum speed plus uniformity in thermocycling is the rapid direct rotary dipping of thin-walled sample tubes into intensely stirred and precisely thermoregulated, segmentally arranged water baths. This arrangement virtually eliminates any differences in thermal exposure between samples. This uniformity is in marked contrast to thermocyclers which heat metal blocks.

\section{Hot Start Procedure}

The hot start procedure results in substantial improvement of amplification efficiency of low-copy number targets. It reduces the influence of varying amounts of background DNA on cycle efficiency that results from the initially occurring false binding of primers at temperatures below the annealing point. This enhances overall sensitivity, and sample-to-sample variation resulting from background DNA is reduced. Technically, it requires the initiation of amplification/polymerization at temperatures clearly above the annealing temperatures for the given primer pair. Traditionally, hot starting is done by adding a wax bead to each tube which, while still in the clean pre-PCR environment, is molten and solidifies as a septum above which further essential components of the polymerization reaction are placed. Inside the thermocycler, the wax septum melts again and floats to the top, thereby generating a synthesis-competent mix. Aside from being cumbersome, the biggest problem is the slow and unpredictable mixing of the two phases. In our system, the hot start procedure is performed in a special machine that becomes an integral part of the thermocycling system and allows the simultaneous heating of the lower part of the sealed tubes containing the PCR mix minus an essential component for the polymerization reaction, that is later introduced simultaneously from a reservoir inside the sealed tubes. This provides for even mixing at the high temperature (approximately $80^{\circ} \mathrm{C}$ ) after all the reaction components are assembled and thermocycling starts immediately. This elimination of tube-to-tube variation in hot starting is essential to harness the strong potential of this method for quantitative PCR.

\section{Densitometric Evaluation of Band Intensity Development Over Time}

Probe-bound alkaline phosphatase catalyzes the formation of insoluble dye polymers from NPT/X-phosphate precursors at the locations of bands on the membrane. For a given set of standards, some are below and some are above an intensity that it useful for quantitation. Therefore, to use each standard in its optimum range, the Southern blot membrane is scanned at intervals during colorimetric dye development to help ascertain the time point at which the derived standard curve is most linear. Each membrane contains quantity standards of post-PCR material generated from serial dilutions of a known copy number $(1,10,100,1,000$ and sometimes 10,000 copies) of cloned pBR322 containing the HIV-1 gag sequence (Perkin-Elmer). The blots are scanned at $300 \mathrm{dpi}, 256-$ level gray scale, $100 \%$ size using a Microtek $300 \mathrm{GZ}$ flatbed scanner in conjunction with Adobe Photoshop ${ }^{\mathrm{rm}}$ software. An image processing program (Image version 1.47 written by Wayne Rasband, N.I.H.) is then used to manually identify and outline bands (image particles) and quantify band area and mean band density. The product of band area and mean density provides a reliable indication of the amount of "blackness" present in a band, and is used in conjunction with the derived standard curve on the same membrane to obtain a numerical value of RNA or DNA viral copy number for each band. 


\section{Application of Automated Quantitative PCR for the Study of HIV Neuro- logic Disease}

Several recent papers have attempted using quantitative PCR to measure proviral load in blood, brain tissue, and CSF with relatively small numbers of subjects.10-13 The methods for PCR quantitation vary in these papers from simple visual comparisons to the complex and labor-intensive quantitative competitive PCR.14-16 We initially attempted to quantify the number of HIV-1 proviral copies per $1,000 \mathrm{CD} 4+$ cells in CSF and blood in relationship to the stage of infection and HIV-1 neurologic disease (HND) in order to find prognostic indicators of HIV disease progression. A related purpose was to provide direct evidence of the presence of HIV-1 in the CNS in vivo, as suggested by recent findings. $17-19$

\section{Cohort Study Subjects}

Eighty-seven HIV-1 seropositive males without CNS opportunistic infections, tumors or neurosyphilis, and 9 high-risk seronegative controls underwent a structured interview, as well as physical and neurologic examination followed by blood and CSF collection. Laboratory tests confirmed that the subjects were free of CNS opportunistic infections, tumors, and neurosyphilis; blood and CSF were collected in a standardized fashion and nucleic acids were extracted immediately. The blood and/or CSF of 14 (DNA studies) and 18(RNA studies) not-at-risk seronegative controls were obtained from the National Neurological Research Specimen Bank (NNRSB).20

At the time of the examination, seropositive subjects were classified into three groups based on the infectious disease questionnaire and the physical examination. Asymptomatic seropositive (ASP) subjects were defined as HIV-1 antibody seropositive patients (with or without lymphadenopathy) with no opportunistic infections or other systemic manifestations of HIV-1. The category corresponds roughly to the Centers for Disease Control (CDC) Groups II and $\Pi I, 21$ which was in effect at the time this study was initiated. AIDS-related complex (ARC) was defined by the presence of one or more of the following: oral candida; oral hairy leukoplakia; herpes zoster in the past 3 years; chronic intermittent diarrhea of at least one-month duration with at least 3 liquid stools/day by work-up without definable cause; weight loss in the past 3 years of at least 10 pounds or $10 \%$ of the body weight, without a definable cause; drenching wholebody night sweats on at least 3 occasions in the previous 3 months; recorded temperatures of at least $100^{\circ} \mathrm{F}$ for at least one month; chronic fatigue which interferred with normal activity at least twice weekly for the past 6 months; and recurrent seborrheic dermatitis or tropical pruritic folliculitis. This category is more inclusive than the CDC groups IVa and Vc2.21 AIDS was defined as follows: medically documented episodes of Pneumocystis carinii pneumonia, extraintestinal strongyloidosis, isopsoriasis, esophageal or bronchial candidiasis; Mycubacterium avium intracellulaire or $M$. kansasii infection; chronic, mucocutaneous herpes simplex or disseminated herpes simplex; cytomegalovirus infection (nonneurologic); or other infections listed by the CDC as AIDS-defining infections, but not involving the CNS; biopsy-documented Kaposi's sarcoma, lymphoma or other syndromes such as chronic lymphoid interstitial pneumonitis, or wasting syndrome. We did not use CD4 cell counts or "HIV-1 encephalopathy" as an AIDS-defining diagnosis. This category corresponded roughly to the CDC group IV, except it does not include CDC groups IVa or IVb.21

On the basis of history and neurologic examination subjects were categorized neurolugically as follows: neurologically negative (NeuroNeg), which was defined as the absence of HIV-1-related neurologic signs and symptoms; and neurologically positive (Neurol'os), which was defined as the documented presence of HIV-1 related neurologic signs and symptoms. Neurologic disease un related to HIV-1 was not used to define either of these categories. HIV-1-related HND was subclassified as cognitive, CNS motor (weakness, spasticity, incoordination, movement disorder) or peripheral neuropathy. Behavioral abnor- 
malities (e.g., depression) were evaluated, but did not contribute to a diagnosis of NeuroPos. The severity grading system (mild, moderate and severe) for HND was adapted from the ADS Treatment Evaluation Unit clinical trial number 005 protocol. 22

Lumbar puncture (LP) was performed in a standardized fashion and CSF (25 cc) was collected into a $30-\mathrm{ml}$ syringe. An aliquot was taken for cell counts, and the remaining fluid was centrifuged to concentrate the cells. Routine clinical CSF testing included white and red blood cell (RBC) counts, glucose, total protein , and VDRL. Cultures, cytology and serologies were ordered when clinically indicated. Because of the sensitivity of the PCR reaction, any blood introduced in to the CSF specimen because of LP-induced trauma could falsely promote positive HIV findings in the CSF. Therefore, only LPs with RBC counts less than 30 cells $/ \mathrm{mm}^{3}$ were used for PCR analyses.

Negative controls for blood and CSF consisted of 9 seronegatives at high risk for HIV-1 infection, of whom 5 had concurrent CSF and blood collections, and 14 paired blood/CSF seronegative control specimens with no known risk for HIV infection were obtained from the NNRSB.

\section{Proviral DNA Load Calculations}

Proviral loads were calculated using the following formulae that were based on the findings of many investigators that the overwhelming cell type infected in the blood is the CD4+ cell.23-26 Flow cytometric analysis was also used on selected CSF samples to confirm the notion that the percentage of CD4+ cells in the CSF cells is close to the $\mathrm{CD} 4+$ percentage of peripheral blood mononuclear cells.

Number of blood $\mathrm{CD} 4+$ cells added to each $\mathrm{PCR}$ reaction $=$

$\left(\mathrm{CD} 4+\right.$ cells in blood $\left./ \mathrm{mm}^{3}\right)\left(\mathrm{ml}^{2}\right.$ whole bloodb $)\left(1,000 \mathrm{~mm}^{3} / \mathrm{ml}\right)(0.68 \mathrm{c})$

$(0.05$ fraction added $) \mathrm{d}$

Number of CSF CD4 + cells added to each PCR reaction $=$

$\left(\mathrm{CD} 4+\right.$ cells in CSFe $\left./ \mathrm{mm}^{3}\right)(\mathrm{ml} \mathrm{CSFf})\left(1,000 \mathrm{~mm}^{3} / \mathrm{ml}^{2}\right)(0.125$ fraction addedd $)$

where:

a Determined by flow cytometry. 27

bBlood used ranged from 4-7 ml, mean $\pm 1 \mathrm{SD}=4.5 \pm 0.3 \mathrm{ml}$.

cPeripheral blood mononuclear cell recovery is on average $68 \pm 13 \%$ with the Ficoll-Hypaque kit (Sigma) used.

dVolume fraction of nucleic acid preparation used for each PCR reaction.

eSince we did not determine directly the number of CD4 + cells in the CSF, this number was estimated by multiplying the measured number of CSF mononuclear cells by the CD $4+$ cell concentration in the blood, i.e.:

(CSF mononuclear cells $\left./ \mathrm{mm}^{3}\right)\left(\frac{\mathrm{CD} 4+\text { cells in blood } / \mathrm{mm}^{3}}{\left.\text { (blood lymphocytes } / \mathrm{mm}^{3}\right)}\right)$ based on the finding

that the CD4+ cell concentrations in blood and CSF were essentially the same. 28,29

fCSF used ranged from $8-22 \mathrm{ml}$, mean $\pm 1 \mathrm{SD}=18.0 \pm 4.0 \mathrm{ml}$.

The number of HIV-1 proviral DNA copies determined by band image analysis for the respective blood or CSF specimen were then divided by the numbers of $\mathrm{CD} 4+$ cells calculated from these formulae. This ratio was then multiplied by 1,000 to yield the number of copies per $1,000 \mathrm{CD} 4+$ cells. 


\section{RESULTS}

All seropositive subjects were ambulatory and living in the community. The demographic, functional and laboratory profiles are presented in Tables 1-3.

Table 1. Demographic profile of HIV-1 high-risk seronegative and seropositive individuals.

\begin{tabular}{l|c|cc}
\hline & $\begin{array}{c}\text { HIV-1 } \\
\text { Seronegative } \\
(\mathrm{n}=9)\end{array}$ & $\begin{array}{c}\text { HIV-1 } \\
\text { Seropositive } \\
(\mathrm{n}=87)\end{array}$ & $\begin{array}{c}\text { P- } \\
\text { VALUE }\end{array}$ \\
\hline Age (years) & $41.1 \pm 8.6 \dagger$ & $38.7 \pm 8.6$ & $.4452^{*}$ \\
Risk Factor (percent of cases) & $89 \%$ & $90 \%$ & \\
$\quad$ Homosexual or Bisexual & $11 \%$ & $10 \%$ \\
$\quad$ Homosexual or Bisexual \& IV Drug Use & 0 & $20 \%$ \\
Source (percent of cases) & $100 \%$ & $80 \%$ \\
$\quad$ Clinic or Physician Referrals & & \\
$\quad$ Community self-referrals through & advertisements \\
T mean tone standard deviation & \\
* p-value, probability level from t-test comparing HIV-1 seropositive and seronegative \\
subjects
\end{tabular}

Table 2. Disability status of seropositive individuals.

\begin{tabular}{|c|c|c|c|c|c|}
\hline & \multicolumn{3}{|c|}{$\begin{array}{l}\text { HIV-1 Systemic } \\
\text { Disease Stage }\end{array}$} & \multicolumn{2}{|c|}{$\begin{array}{l}\text { HIV-1 Neurologic } \\
\text { Disease }\end{array}$} \\
\hline Disability Variable & ASP & ARC & AIDS & $\begin{array}{l}\text { Neuro } \\
\text { Neg }\end{array}$ & $\begin{array}{l}\text { Neuro } \\
\text { Pos }\end{array}$ \\
\hline $\begin{array}{l}\text { Functional } \\
\text { Work Status - \% of cases (\#) }\end{array}$ & $n=34$ & $n=46$ & $n=7$ & $n=60$ & $n=27$ \\
\hline Working full time & $97 \%(33)$ & $61 \%(28)$ & $14 \%(7)$ & $88 \%(53)$ & $33 \%(9)$ \\
\hline Working part time & $0 \%$ & $9 \%(4)$ & $14 \%(1)$ & $2 \%(1)$ & $15 \%(4)$ \\
\hline $\begin{array}{l}\text { Unemployed / Unable to } \\
\text { Work }\end{array}$ & $3 \%(1)$ & $30 \%(14)$ & $71 \%(5)$ & $10 \%(6)$ & $52 \%(14)$ \\
\hline $\begin{array}{l}\text { Kamofsky Index of } \\
\text { Performance }\end{array}$ & & & & & \\
\hline $\begin{array}{l}\% \text { of cases }(\#) \\
100 \% \text { of Normal }\end{array}$ & 8707 & 2500 & & & \\
\hline Functioning & $82 \%(28)$ & $35 \%(10)$ & $14 \%(1)$ & $68 \%(41)$ & $15 \%(4)$ \\
\hline $90 \%$ & $12 \%(4)$ & $20 \%(9)$ & $0 \%(0)$ & $15 \%(9)$ & $15 \%(4)$ \\
\hline $80 \%$ & $6 \%(2)$ & $24 \%(11)$ & $14 \%(1)$ & $12 \%(7)$ & $26 \%(7)$ \\
\hline 50,60 or $70 \%$ & $0 \%(0)$ & $22 \%(10)$ & $71 \%(5)$ & $5 \%(3)$ & $44 \%(12)$ \\
\hline $\begin{array}{l}\text { Neurologic Disease } \\
\% \text { of cases (number) }\end{array}$ & & & & & \\
\hline None & $91 \%(31)$ & $61 \%(28)$ & $14 \%(1)$ & $100 \%$ & $0 \%(0)$ \\
\hline Mild & $6 \%(2)$ & $15 \%(7)$ & $14 \%(1)$ & $0 \%(0)$ & $37 \%(10)$ \\
\hline Moderate & $3 \%(1)$ & $24 \%(17)$ & $71 \%(5)$ & $0 \%(0)$ & $63 \%(17)$ \\
\hline Severe & $0 \%(0)$ & $0 \%(0)$ & $0 \%(0)$ & $0 \%(0)$ & $0 \%(0)$ \\
\hline $\begin{array}{c}\text { Anti-retroviral Treatment } \\
\% \text { of cases }(\#)\end{array}$ & & & & & \\
\hline None & $62 \%(21)$ & $20 \%(9)$ & $0 \%(0)$ & $47 \%(28)$ & $22 \%(6)$ \\
\hline $\begin{array}{l}\text { Treated at tine of } \\
\text { examination }\end{array}$ & $38 \%(13)$ & $80 \%(37)$ & $100 \%(9)$ & $53 \%(32)$ & $78 \%(21)$ \\
\hline
\end{tabular}


Table 3. Laboratory parameters in HIV-1 seropositive individuals.

\begin{tabular}{|c|c|c|c|c|c|}
\hline \multirow[b]{2}{*}{ Lab Parameter } & \multicolumn{3}{|c|}{$\begin{array}{l}\text { HIV-1 Systemic } \\
\text { Disease Stage }\end{array}$} & \multicolumn{2}{|c|}{$\begin{array}{l}\text { HIV-1 Neurologic } \\
\text { Disease }\end{array}$} \\
\hline & ASP & ARC & AIDS & $\begin{array}{c}\text { Neuro } \\
\text { Neg }\end{array}$ & $\begin{array}{l}\text { Neuro } \\
\text { Pos }\end{array}$ \\
\hline BLOOD & $n=34$ & $n=46$ & $n=7$ & $n=60$ & $n=27$ \\
\hline $\mathrm{CD}^{+}$cell count (cells $/ \mathrm{mm}^{3}$ ) & $637 \pm 260$ & $428 \pm 275$ & $137 \pm 139$ & $581 \pm 268$ & $275 \pm 244$ \\
\hline$\%(\#)<200 \mathrm{CD}^{+}$cells $/ \mathrm{mm}^{3}$ & $6 \%(2)$ & $17 \%(8)$ & $57 \%(4)$ & $7 \%(4)$ & $37 \%(10)$ \\
\hline $200-499 \mathrm{CD} 4^{+}$cells $/ \mathrm{mm}^{3}$ & $21 \%(7)$ & $43 \%(20)$ & $43 \%(3)$ & $33 \%(20)$ & $37 \%(10)$ \\
\hline$\geq 500 \mathrm{CD}^{+}$cells $/ \mathrm{mm}^{3}$ & $73 \%(25)$ & $39 \%(18)$ & $0 \%$ & $60 \%(36)$ & $26 \%(7)$ \\
\hline $\mathrm{CD}^{+}: \mathrm{CD}^{+}$ratio & $.65 \pm .34$ & $.4 \pm .27$ & $.15 \pm .1$ & $.59 \pm .32$ & $.24 \pm .16$ \\
\hline CSF & $n=28$ & $\mathrm{n}=33$ & $\mathrm{n}=6$ & $\mathrm{n}=47$ & $n=20$ \\
\hline Leukocyte count (cells $/ \mathrm{mm}^{3}$ ) & $4.1 \pm 5.6$ & $2.8 \pm 3.0$ & $2.5 \pm 4.7$ & $3.7 \pm 4.7$ & $2.5 \pm 3.3$ \\
\hline$\%$ leukocytes $\geq 5$ cells $/ \mathrm{mm}^{3}$ & $18 \%(5)$ & $15 \%(5)$ & $17 \%(1)$ & $19 \%(9)$ & $10 \%(2)$ \\
\hline $\begin{array}{l}\text { Trans-Blood-Brain-Barrier } \\
\text { Albumin Leakage (AL) Rate } \\
\text { (mg/day) }\end{array}$ & $\begin{array}{c}21.2 \pm \\
31.8\end{array}$ & $\begin{array}{c}44.8 \pm \\
52.5\end{array}$ & $\begin{array}{c}26.7 \pm \\
31.6\end{array}$ & $\begin{array}{l}21.4 \pm \\
28.5\end{array}$ & $\begin{array}{l}61.2 \pm \\
60.7\end{array}$ \\
\hline $\begin{array}{l}\% \text { (\#) abnormal AL Rate } \geq 75 \\
\text { mg/day }\end{array}$ & $7 \%(2)$ & $21 \%(7)$ & $0 \%$ & $2 \%(1)$ & $40 \%(8)$ \\
\hline Intrathecal IgG Synthesis & & & & & \\
\hline By Rate Formula (mg/day) & $10.2 \pm 12$ & $22.8 \pm 27$ & $12.4 \pm 9.3$ & $13.6 \pm 16.4$ & $23.6 \pm 29.2$ \\
\hline $\begin{array}{l}\text { By Oligoclonal Bands }(\mathrm{OB}, \#) \\
\% \text { (\#) abnormal by rate }\end{array}$ & $1.9 \pm 2.8$ & 2.2 & $2.5 \pm 1.8$ & $2.0 \pm 2.6$ & $2.2 \pm 2.0$ \\
\hline formula $\geq 3.3 \mathrm{mg} /$ day & $50 \%(14)$ & $70 \%(23)$ & $67 \%(4)$ & $60 \%(28)$ & $65 \%(13)$ \\
\hline $\begin{array}{l}\%(\#) \text { abnormal by } \mathrm{OB} \geq 1 \\
\text { band }\end{array}$ & $50 \%(14)$ & $67 \%(22)$ & $83 \%(5)$ & $55 \%(26)$ & $75 \%(15)$ \\
\hline $\begin{array}{l}\%(\#) \text { abnormal by rate } \\
\text { formula } \geq 6 \mathrm{mg} / \text { day or } \mathrm{OB} \geq \\
1 \text { band }\end{array}$ & $68 \%(19)$ & $85 \%(28)$ & $100 \%(6)$ & $74 \%(35)$ & $90 \%(18)$ \\
\hline
\end{tabular}

Table 4 shows results for the detection of HIV-1 provirus in blood CD4+ cells. Ninety-three percent of the HIV-1 seropositives had positive PCRs for HIV1 provirus detection (Table 4A). There were no significant differences in frequency of positive PCRs among either the systemic or neurologic subgroups (Table 4B). A single HIV-1 seronegative high-risk control showed a positive PCR, and this result was confirmed on a subsequent sample, although the subject's ELISA and Western blot remained negative. None of the 14 no known risk controls showed a positive PCR.

Table 5 indicates the detection rate of HIV-1 provirus in CSF cells. Ninety percent of the HIV-1 seropositives were PCR-positive (Table 5A). Two high-risk seronegative controls showed a positive PCR and one of these cases also showed PCR-positive blood. These findings were confirmed on the next CSF sample for each subject. There were no significant differences in frequency of positive PCRs among either the systemic or neurologic subgroups (Table 5B). None of the 14 no known risk controls were PCR positive. 
Table 4A. Frequency of HIV-1 proviral detection by PCR in blood CD4+ cells in HIV-1 seronegative and seropositive individuals.

\begin{tabular}{l|c|c|c} 
& \multicolumn{2}{|c|}{ HIV-1 Seronegative } & No-known \\
& $\begin{array}{c}\text { Nisk factors } \\
\text { PCR Result }\end{array}$ & High Risk & Heropositive \\
& $n=14$ & $n=9$ & $n=87$ \\
\hline Negative & $100 \%(14 / 14)$ & $89 \%(8 / 9)$ & $7 \%(6 / 87)$ \\
Positive & $0 \%(0 / 14)$ & $11 \%(1 / 9)$ & $93 \%(81 / 87)$ \\
\hline
\end{tabular}

Table 4B. Frequency of HIV-1 provirus detected by PCR in blood CD4 + cells in clinically classified HIV-1 seropositive individuals.

\begin{tabular}{l|c|c|c||c|c}
\hline \multicolumn{3}{c}{ HIV-1 Systemic Disease Stage } & \multicolumn{2}{c}{ HIV-1 Neurologic Disease } \\
PCR Results & ASP & ARC & AIDS & NeuroNeg & NeuroPos \\
\hline Negative & $12 \%(4 / 34)$ & $4 \%(2 / 46)$ & $0 \%(0 / 7)$ & $10 \%(6 / 60)$ & $0 \%(0 / 27)$ \\
Positive & $88 \%(30 / 34)$ & $96 \%(44 / 46)$ & $100 \%(7 / 7)$ & $90 \%(54 / 60)$ & $100 \%(27 / 27)$ \\
\hline
\end{tabular}

Table 5A. Frequency of HIV -1 provirus detection by PCR in CSF CD $4+$ cells in HIV-1 seronegative and seropositive individuals.

\begin{tabular}{l|c|c|c}
\hline & \multicolumn{2}{|c|}{ HIV-1 Seronegative } & Ho-known \\
PCR Result & risk factors & High Risk & $\begin{array}{c}\text { HIV } 1 \\
\text { Seropositive }\end{array}$ \\
\hline Negative & $100 \%(14 / 14$ & $60 \%(3 / 5)$ & $10 \%(6 / 63)$ \\
Positive & $0 \%(0 / 14)$ & $40 \%(2 / 5)$ & $90 \%(57 / 63)$ \\
\hline
\end{tabular}

Table 5B. Frequency of HIV-1 provirus detection by PCR in CSF CD4+ cells in clinically classified HIV-1 seropositive individuals.

\begin{tabular}{l|c|c|c||c|c}
\hline \multirow{2}{*}{ PCR Results } & \multicolumn{2}{|c||}{ HIV-1 Systemic Disease Stage } & \multicolumn{2}{c}{ HIV-1 Neurologic Disease } \\
\hline Negative & ASP & ARC & AIDS & NeuroNeg & NeuroPos \\
Positive & $85 \%(4 / 26)$ & $3 \%(1 / 31)$ & $17 \%(1 / 6)$ & $10 \%(4 / 42)$ & $10 \%(2 / 21)$ \\
\hline & $85 \%(22 / 26)$ & $97 \%(30 / 31)$ & $83 \%(5 / 6)$ & $90 \%(38 / 42)$ & $90 \%(19 / 21)$ \\
\hline
\end{tabular}


The proviral DNA loads for blood and CSF cells from subjects who had both CSF and blood specimens at the same visit are presented in Table 6. In blood $\mathrm{CD} 4$ + cells, the median number of proviral copies $/ 1,000$ cells for all seropositive subjects was 0.6; whereas, in CSF the median number was 25. The CSF proviral load was significantly greater than that for blood over all seropositive subjects $(p=0.0001)$. Proviral load also varied as a function of HIV-1 disease status. For blood CD4 + cells, the number of proviral copies/1,000 cells was significantly different among ASP, ARC and AIDS subgroups, with proviral load lowest for ASP ( 0.09 copies $/ 1,000$ cells), higher for ARC ( 1.4 copies $/ 1,000$ cells) and highest for AIDS (10.7 copies $/ 1,000$ cells). Similarly, the proviral load in blood CD $4+$ cells was significantly greater in NeuroPos than in NeuroNeg individuals. For CSF cells, there was a trend for proviral load to be greater in NeuroPos (43.5 copies/ 1,000 cells) than in NeuroNeg (17.6 copies/ 1,000 cells) individuals. In addition, CSF proviral load differed significantly as a function of HIV-1 systemic disease status, against lowest in ASP and highest in AIDS $(p=0.0316)$. The effects of anti-retroviral therapy could not be adequately evaluated because this comparison was confounded by the fact that the subjects on treatment had significantly lower mean CD4 + cell counts than those not on treatment ( $p=0.0001$ ); that is, subjects on treatment generally had more advanced HIV-1 disease than those not on treatment.

Table 6. HIV-1 proviral DNA load ${ }^{\dagger}$ in blood and CSF CD4 + cells from HIV-1 seropositive individuals with concurrent CSF and blood samples.

\begin{tabular}{|c|c|c|c|}
\hline GROUP & Blood & CSF & P-Value \\
\hline $\begin{array}{rr}\text { All Seropositives ( } \mathrm{n}=63 \text { ) } & \text { median } \\
\text { inter-quartile range }\end{array}$ & $\begin{array}{c}0.6 \\
0.04-4.0\end{array}$ & $\begin{array}{c}25 \\
2.4-144\end{array}$ & $.0001^{*}$ \\
\hline $\begin{array}{r}\text { A symptomatic seropositive }(\mathrm{ASP})(\mathrm{n}=26) \\
\text { median } \\
\text { inter-quartile range } \\
\end{array}$ & $\begin{array}{c}0.09 \\
0.01-1.1 \\
\end{array}$ & $\begin{array}{c}10.5 \\
0.32-53 \\
\end{array}$ & \\
\hline $\begin{array}{r}\text { median } \\
\text { inter-quartile range }\end{array}$ & $\begin{array}{c}1.4 \\
0.17-11.5\end{array}$ & $\begin{array}{c}54 \\
12.5-206\end{array}$ & \\
\hline $\begin{array}{r}\text { median } \\
\text { inter-quartile range }\end{array}$ & $\begin{array}{c}10.7 \\
0.04-54\end{array}$ & $\begin{array}{c}155 \\
5.6-1160\end{array}$ & \\
\hline ASP vs. ARC vs. AIDS & $\mathrm{p}=0.0281 * *$ & $\mathrm{p}=0.0316^{* *}$ & \\
\hline $\begin{array}{rr}\text { NeuroNegative }(\mathrm{n}=42) & \text { median } \\
& \text { inter-quartile range }\end{array}$ & $\begin{array}{c}0.4 \\
0.02-2.5\end{array}$ & $\begin{array}{c}17.6 \\
1.2-95\end{array}$ & \\
\hline $\begin{array}{rr}\text { NeuroPositive }(n=21) & \text { median } \\
& \text { inter-quartile range }\end{array}$ & $\begin{array}{c}1.6 \\
0.1-21.2\end{array}$ & $\begin{array}{c}43.5 \\
12.2-747\end{array}$ & \\
\hline NeuroNegative vs. NeuroPositive & $\mathrm{p}=0.0357^{* * *}$ & $\mathrm{p}=0.0614^{* * *}$ & \\
\hline
\end{tabular}


The frequency of HIV-1 RNA detection in serum (at 40 cycles of PCR amplification) was $93 \%(62 / 67)$ for al seropositive subjects (Table $7 \mathrm{~A}$ ) and did not vary significantly with HIV-1 disease status or the presence of neurologic disease (Table 7B). Table 8 shows that HIV-1 RNA was significantly related to CD4+ cell count. The RNA values were highest in seropositive subjects with counts less than 200 cells $/ \mathrm{mm}^{3}$ and lowest in those with counts at or above 500 cells $/ \mathrm{mm}^{3}$. The RNA detection frequency was less in CSF than in serum, but the CSF data are still being evaluated. Preliminary quantitative evaluation of CSF RNA suggests lower amounts than in the serum.

Table 7A. Frequency of HIV-1 RNA detection by PCR in serum of HIV-1 seronegative and seropositive individuals.

\begin{tabular}{l|c|c|c}
\cline { 2 - 4 } & $\begin{array}{c}\text { HIV-1 } \\
\text { Seronegative } \\
\text { Low Risk } \\
\mathrm{n}=18\end{array}$ & $\begin{array}{c}\text { HIV-1 } \\
\text { Seronegative } \\
\text { High Risk } \\
\mathrm{n}=6\end{array}$ & $\begin{array}{c}\text { HIV-1 } \\
\text { Seropositive } \\
\text { All Stages } \\
\mathrm{n}=67\end{array}$ \\
\hline Negative & $100 \%(18 / 18)$ & $83 \%(5 / 6)$ & $7 \%(5 / 67)$ \\
Positive & $0 \%(0 / 18)$ & $17 \%(1 / 6)$ & $93 \%(62 / 67)$ \\
\hline
\end{tabular}

Table 7B. Frequency of HIV-1 RNA detection in serum of clinically classified HIV-1 seropositive individuals.

\begin{tabular}{l|c|c|c||c|c}
\hline & \multicolumn{3}{|c||}{ HIV-1 Systemic Disease Stage } & \multicolumn{2}{c}{ HIV-1 Neurologic Disease } \\
PCR Results & ASP & ARC & AIDS & NeuroNeg & NeuroPos \\
\hline Negative & $8 \%(2 / 25)$ & $8 \%(3 / 36)$ & $0 \%(0 / 0)$ & $10 \%(5 / 44)$ & $0 \%(0 / 18)$ \\
Positive & $92 \%(23 / 25)$ & $92 \%(33 / 36)$ & $100 \%(6 / 6)$ & $90 \%(44 / 49)$ & $100 \%(18 / 18)$ \\
\hline \multicolumn{3}{c}{$p=0.766$, Chi-Square $=0.53$} & & $p=3.35$, Chi-Square $=0.341$
\end{tabular}

Table 8. HIV-1 RNA in serum from HIV-1 seropositive individuals: relationship to $\mathrm{CD} 4+$ cell counts.

\begin{tabular}{l|c}
\cline { 2 - 2 } GROUP & Serum RNA* \\
\hline \hline $\begin{array}{l}\text { CD4 }{ }^{+} \text {cell count } \\
0-199 \text { cells } / \mathrm{mm}^{3}(\mathrm{n}=11)\end{array}$ & 100,000 \\
\hline $200-499$ cells $/ \mathrm{mm}^{3}(\mathrm{n}=23)$ & 53,000 \\
\hline$\geq 500$ cells $/ \mathrm{mm}^{3}(\mathrm{n}=31)$ & 12,000 \\
\hline $\begin{array}{l}\text { Comparison among CD4 } \\
\text { * } \text { cell groups, } \mathrm{p}=0.0041\end{array}$ \\
${ }_{\text {Median copies per } \mathrm{ml}}$
\end{tabular}




\section{DISCUSSION}

\section{PCR Blood Results}

We found that $94 \%$ of the HIV-1 seropositive blood specimens were PCRpositive using two HIV-1 gag region primers and that the detection frequency was not related to either systemic or neurologic disease status. The overall detection frequency is similar to that reported for peripheral blood mononuclear cells in other HIV studies. $30-35$

The quantified proviral DNA data suggest that the level of HIV-1 infection in blood CD4 + cells is highly variable, but related to disease status. The absolute proviral load values reported here are similar to those reported elsewhere, and also confirm that the highest levels of infection occur in subjects with more advanced HIV-1 disease. $10,26,33,36$ These data indicate that in the later stages of HIV-1 infection, the relative proviral load in blood CD4 + cells increases substantially and may be the basis for the rapid decline of $\mathrm{CD} 4+$ cells seen in these patients. 35

\section{PCR CSF Findings}

A few investigators have extended PCR detection of HIV to the CSF and compared directly the results in blood and CSF.17,18,37 If we discount the patients with opportunistic infections and CNS lymphoma, Shaunak and colleagues 17 had a positive HIV-1 PCR detection rate of only $60 \%(9 / 15)$. In contrast, we report here a detection rate of $90 \%(19 / 21)$ in the subgroup who were NeuroPos and without opportunistic infection, tumor, or neurosyphilis. Likewise, we also report a higher detection rate in subjects without neurologic findings $(38 / 42$, or $90 \%)$ than did Shaunak et al. (1/7, or $14 \%) .17$ The differences in detec-tion rates between our CSF findings and those of Shaunak and colleagues may stem from methodologic or sensitivity issues. Further support for this explanation and our results can be found in a paper by Sönnerberg and colleagues 18 who performed a series of experiments which most closely parallel our work on PCR detection of HIV in CSF; however, they did not quantitate the PCR results. They performed PCR on 28 seropositive patients, 24 of whom showed no neurologic signs, and reported a PCR detection rate of $86 \%$ in the CSF.

In the only other paper dealing with proviral load in CSF, Steuler et al report amounts of virus in the CSF similar to those we report here. 37 In contrast to our results, they reported that the HIV-1 proviral load in CSF cells did not correlate with CDC disease stage. However, 7 of their 13 patients had a CNS opportunistic infection. Additionally, Steuler and colleagues used a different form of proviral quantitation than we employed so results are not directly comparable. However, their results provide some corroborating evidence that the level of HIV-1 provirus in the CSF cells is higher per cell than that reported in peripheral blood.

\section{What Is the Source of HIV -1 Proviral DNA in CSF Cells?}

There is sparse knowledge regarding the source and migration of lymphocytes and monocytes in the brain and CSF. While it is generally accepted that HIV is initially introduced into the CNS intracellularly aboard infected monocytes, its further mode of propagation inside the CNS is unknown. Although others have not observed virus-expressing lymphocytes within the HIV-infected brain, our data indicate that at least a substantial portion of the cells in the CSF are indeed carrying the HIV proviral genome.

We find a frequency of infection of CSF cells almost equal to that in blood. Autopsy studies have shown the presence of HIV DNA determined by PCR in all cases with evidence of encephalitis and similarly, Pang and colleagues 12 found HIV proviral DNA in $90 \%$ of all cases with postmortem evidence of HIV encephalitis. In a case of severe accidental inoculation with HIV, the virus was detectable in the brain after 15 days with no signs of encephalitis. Additionally, Masliah and colleagues found that although only $16 \%$ of the cases they examined 
showed histologic signs of HIV-1 encephalitis, up to $50 \%$ had moderate to severe HIV-1 infection. 38 Golswami and colleagues using HIV RNA PCR found 23 of 24 patients with neurodisease were HIV RNA positive in the CSF, but not 4 of 20 asymptomatic patients. These conflicting results are likely to be caused by a variation in the sensitivity of the PCR assay that was actually used.

In an attempt to explain the surprisingly high frequency of proviral DNA per CSF cell, it seems likely that of the variety of mechanisms that have been shown or are suspected to reduce the number of infected (and uninfected) CD4 + cells in peripheral blood via immunoreactive means most will be less rigorously effective in eliminating cells in the CSF, where the infection can spread more readily among the few available $\mathrm{CD} 4+$ cells. In addition, the brain might act as a continuous extravascular source of HIV. More esoteric possibilities include that there is some unknown selection method that concentrates infected cells from blood in the CSF, and that this mechanism accounts for the disproportionate level of proviral infected cells in the CSF. Another notion is that there is some permissive factor which allows HIV-1 to replicate more readily in the CSF than in blood.

The studies of Gendelman et al.4, as well as others, localize HIV-1 in brain microglia and macrophages, where they appear to thrive as suggested by electron micrographs that show budding virions. Pathologic studies indicate that deep brain regions are frequently the site of intense HIV encephalitis, and that these regions are in turn characterized by the presence of multinucleated giant cells. 39,40 Accordingly, it is possible that there may be exfoliation of HIV-1 laden monocytes (histiocytes) into the ventricular CSF, 41 an extension of the extracellular space of the brain, from deep brain regions. This hypothesized movement from infected brain to CSF may account for the higher CSF proviral load when compared to blood. This concept is supported by our data that higher levels of HIV-1 provirus in the CSF were associated with the presence of clinical neurologic disease. Another hypothesis is that there may be an unknown selection method in the choroid plexus, the main source of CSF. In this view, the choroid plexus preferentially sequesters HIV-1-infected blood CD4+ cells and passes them in to the CSF. To our knowledge, nobody has done a systematic histopathological study of the choroid plexus in HIV-1 brain to check for pathology.

Another notion is that infected CSF cells release virions which in turn infect over CD4 + cells. This reinfection may be facilitated in the CSF because of a higher concentration to activate $T$ cells 42 and less rigorous immune surveillance.

\section{SIGNIFICANCE}

Determinations of proviral DNA load and replicative activity by HIV RNA PCR could serve as useful prognostic tools for CNS involvement of HIV disease in individual patients. Our findings further support the theory that an important aspect of HIV chronicity could be the continuous shedding of virus from the immunoprivileged CNS/CSF into the main circulation. A related notion is that the virus uses the CNS/CSF as a breeding ground for variants that are resistant against the body's natural defenses. Under this hypothesis, these variants would not have had the necessary time to develop in the immunoactive area of the body. It is known that the initial immune response against HIV is strong and effective. If a significant amount of virus is produced in the CNS/CSF then the continuous backflow through the natural exit of the CSF, the arachnoid villus, at $500 \mathrm{ml}$ per day, could amount to a very substantial source of reinfection from an unattack able reservoir. Similar considerations apply to the use of initially effective drugs that are excluded from the CNS.

$\mathrm{CSF}$ is an easily obtainable fluid. In ongoing and future clinical therapeutic trials, where direct measurement of level of free virions in blood using quantitative HIV RNA PCR will soon be used widely, it might be important to determine the CSF viral load in collateral measurements. This will likely be a good indicator of the response of the brain infection to the therapy. If a tested drug does not pass the blood-brain barrier or is not effective inside the CNS, 
resistant variants will have a chance to form within this protected space and eventually reinfect the body.

\section{ACKNOWLEDGMENTS}

We express special appreciation to Peter Ruane, M.D. and Paul Singer, M.D. for assistance in recruitment and clinical classification of subjects; Carol Silbar, R.N., John Zhang, Ph.D., and Julie Kim, B.A., for their efforts in coordinating the HIV-1 project; Dan Stokes and Eugene Chiang, B.A., for laboratory analyses of CSF; Iris Rosario, R.N., for her coordination of the staff and activities of the NNRSB; and Giane Guntrip, Deborah Kovac, Diane Varnas, and Gerald Synder for admnistrative assistance.

\section{REFERENCES}

1. B.A. Navia, B.D. Jordan, and R.W. Price. The AIDS dementia complex. I. Clinical features. Ann. Neurol. 19:517 (1986).

2. American Academy of Neurology: Nomenclature and research case definitions for neurologic manifestations of human immunodeficiency virus type 1 (HIV-1) infection. Report of a Working Group of the American Academy of Neurology AIDS Task Force. Neurology 41:778 (1991).

3. L.R. Sharer. Pathology of HIV-1 infection of the central nervous system. A review. J. Neuropath. Exp. Neurol. 51:3 (1992).

4. H.E. Gendelman, J.M. Orenstein, L.M. Baca, et al. The macrophage in the persistence and pathogenesis of HIV infection. AIDS 3:375 (1989).

5. A. Rolfs, I. Schuller, U. Finckh, and I. Weber-Rolfs. PCR: Clinical Diagnostics and Research. Springer-Verlag, New York (1992).

6. F. Ferre. Quantitative or semiquantitative PCR: reality versus myth. $P C R$ Methods and Applications 1:21 (1992).

7. J.G. Wetmur. DNA probes, applications of the principles of nucleic acid hybridization. Crit. Rev. Biochem. Mol. Biol. 26:227 (1991).

8. S. Kaneko, R.H. Miller, S.M. Feinstone, et al. Detection of serum hepatitis B virus DNA in patients with chronic hepatitis using the polymerase chain reaction assay. Proc. Natl. Acad. Sci. USA 86:312 (1989).

9. S. Kaneko, M.S. Feinstone, and r.h. Miller. Rapid and sensitive method for the detection of serum hepatitis B virus using the polymerase chain reaction technique. J.Clin. Microbiol. 27:1933 (1989).

10. M.T. Schechter, P.W. Neumann, M.S. Weaver, et al. Low HIV-1 proviral DNA burden detected by negative polymerase chain reaction in seropositive individuals correlates with slower disease progression. AIDS $5: 373(1991)$.

11. E. Stoeckl, N. Barrett, F.X. Heinz, et al. Efficiency of the polymerase chain reaction for the detection of human immunodeficiency virus type 1 (HIV1) DNA in the lymphocytes of infected persons: comparison of antigenenzyme-linked immunosorbent assay and virus isolation. J.Med.Virol. 29:249 (1989).

12. S. Pang, Y. Koyangi, S. Miles, et al. High levels of unintegrated HIV-1 DNA in brain tissue of AIDS dementia patients. Nature 343:85 (1990).

13. L.E. Davis, B.L. Hjelle, V.E. Miller, et al. Early viral brain invasion in iatrogenic human immunodeficiency virus infection. Neurology 42:1736 (1992).

14. M. Stieger, C. Démollière, L. Ahlborn-Laake, and J. Mous. Competitive polymerase chain reaction assay for quantitation of HIV-1 DNA and RNA. J. Virol. Meth. 34:149(1991).

15. A. Teleni, P. Imboden, and D. Germann. Competitive polymerase chain reaction using an internal standard: application to the quantitation of viral DNA. J. Virol. Meth $39: 259$ (1992).

16. M.J. Piatak, K.C. Luk, B. Williams, and J.D. Lifson. Quantitative competi- 
tive polymerase chain reaction for accurate quantitation of HIV DNA and RNA species. Biotechniques 14:70 (1993).

17. S. Shaunak, R.E. Albright, M.E. Klotman, et al. Amplification of HIV-1 provirus form cerebrospinal fluid and its correlation with neurologic disease. J.Infect. Dis. 161:1068(1990).

18. A.B. Sönnerborg, B. Johansson, and O,. Strannegard. Detection of HIV-1 DNA and infectious virus in cerebrospinal fluid. AIDS Res. Human Retroviruses 7:369 (1991).

19. H. Steuler, B. Storch-Haglenlocher, and B.Wildemann., Distinct populations of human immunodeficiency virus type 1 in blood and cerebrospinal fluid. AIDS Res. Human Retroviruses $8^{\prime} 53$ (1992).

20. W.W. Tourtellotte and K. Bermann. Brain Banking. Birkhauser, Boston (1987).

21. Centers for Disease Control: Revision of the CDC surveillance case definition for acquired immunodeficiency syndrome. Morbid. Mortal. Wkly. Rep. 36 (Suppl. 15):1s (1987).

22. National Institute of Allergy and Infectious Diseases ATEU: A multicenter placebo-controlled, double-blind triai to evaluate treatment of the AIDS dementia complex and central nervous system in HIV infection (ATEU 005) (1987).

23. D. Klatzman, F. Brun-Vezinet, C. Rouzioux, et al. Selective tropism of lymphadenopathy-associated virus (LAV) for helper-inducer T lymphocytes. Science 225:59 (1984).

24. S. Gartner, P. Markovits, D.M. Markovits, et al. The role of mononuclear phagocytes in HTLV-II/LAV infection. Science 233:215 (1986).

25. D.D. Ho, T.R. Rota, and M.S. Hirsch. Infection of monocyte/macrophages by human T lymphotropic virus type III. J. Clin. Invest. 77:1712 (1986).

26. S.M. Schnittman, M.C. Psallidopoulos, H,.C. Lane, et al. The reservoir for HIV-1 in human peripheral blood is a T cell that maintains expression of CD4. Science 245:305 (1989).

27. J.L. Fahey, H. Prince, M. Weaver, et al. Quantitative changes in TR helper or T suppressor/cytotoxic lymphocyte subsets that distinguish ADS from other immune subset disorders. Am. J. Med. 76:95 (1984).

28. J.B. Margolick, J.C. McCarthur, E.R. Scott, et al. Flow cytometric quantita tion of cell phenotypes in cerebrospinal fluid and peripheral blood of homosexual men with and without antibodies to human immunodeficiency virus type 1 . d. Neuroimmunol. 20:73 (1988).

29. J.C. McCarthur, E. Sipos, D.R. Cornblath, et al. Identification of mononuclear cells in CSF of patients with HIV infection. Neurology 39:66 (1989).

30. K.Y. Young, J.B. Peter, and R.E. Winters. Detection of HIV DNA in peripheral blood by the polymerase chain reaction: A study of clinical applicability and performance. AIDS 4:389 (1990).

31. L. Ratner. Measurement of human immunodeficiency virus load and is relation to disease progression. AIDS Res. Human Retroviruses 5:115 (1989).

32. F.T. Hufert, D. von Laer, C. Schramm, A. Tärnok, and H. Schmitz. Detection of HIV-1 DNA in different subsets of human peripheral blood mononuclear cells using the polymerase chain reaction. Arch. Virol. 106:341 (1989).

33. F.T. Hufert, D. von Laer, T.E. Fenner, et al. Progression of HIV-1 infection. Monitoring of HIV-1 DNA in peripheral blood mononuclear cells by PCR. Arch. Virol. 120:233 (1991).

34. S. Oka, K. Urayama, Y. Hirabayashi, et al. Quantitative analysis of human immunodeficiency virus type 1 DNA in asymptomatic carriers using the polymerase chain reaction. Biochem. Biophys. Res. Commun. 167:1 (1990).

35. S.M. Schnittman, J.J. Greenhouse, H.C. Lane, P.F. Pierce, and A.S. Fauci. Frequent detection of HIV-1-specific mRNAs in infected individuals suggests ongoing active viral expression in all stages of disease. AIDS Res. Human Retroviruses 7:361 (1991).

36. N.L. Michael, M. Vahey, D.S. Burke, and R.R. Redfield. Viral DNA and 
mRNA expression correlate with the stage of human immunodeficiency virus (HIV) type 1 infection in humans: evidence for viral replication in all stages of HIV disease. J. Virol. 66:310 (1992).

37. H. Steuler, S. Munzinger, B., Wildemann, and B. Strock-Hagenlocher. Quantitation of HIV-1 proviral DNA in cells from cerebrospinal fluid. $J$. AIDS Syndr. 5:405 (1992).

38. E. Masliah, C.L. Achim, N. Ge, et al. Spectrum of human immunodeficiency virus-associated neocortical damage. Ann. Neurol. 32:321 (1992).

39. H. Budka. Human immunodeficiency virus (HIV)-induced disease of the central nervous system: pathology and implications for pathogenesis. Acta Neuropathol. 77:225 (1989).

40. H.V. Vinters, and K.H. Anders. Neuropathology of AIDS. Boca Raton, CRC Press, Inc., 1990.

41. R.L. Katz, C. Alappattu, J.P.Glass, and J.M. Bruner. Cerebrospinal fluid manifestations of the neurologic complications of human immunodeficiency virus infection. Acta Cytol. 33:233 (1989).

42. D.G. Walker, S. Itagaki, K. Berry, and P.L.McGeer. Examination of brains of AIDS cases for human immunodeficiency virus and human cytomegalovirus nucleic acids. J. Neurol. Neurosurg. Psychiatry 52:583 (1989). 